\title{
СЕЛЕКЦИОННАЯ ОЦЕНКА ГЕНОФОНДА ОЗИМОЙ ТРИТИКАЛЕ МИРОВОЙ КОЛЛЕКЦИИ ВИР В УСЛОВИЯХ ПРЕДГОРНОЙ ЗОНЫ СЕВЕРНОГО КАВКАЗА
}

\author{
И.Р. Манукян*, М.А. Басиева ${ }^{* *}$
}

\begin{abstract}
Аннотация. Изучены сортообразцы озимой тритикале мировой коллекции Всероссийского института растениеводства им. Н.И. Вавилова (ВИР) по комплексу хояйственно-ценных признаков. Выделены источники высокой продуктивности зерна, короткостебельности, устойчивости к фузариозу колоса и др. Создана коллекция исходного материала для селекции сортов озимой тритикале, адаптированных к условиям предгорной зоны Северного Кавказа.

Ключевые слова: озимая тритикале, мировая коллекция ВИР, фузариоз колоса, устойчивость.
\end{abstract}

Современная селекция озимой тритикале для Северо-Кавказского региона направлена на создание сортов зернового и кормового типов. Сорта зернового типа характеризуются стабильным и высоким потенциалом урожайности. Сорта должны быть устойчивыми к полеганию, болезням, вредителям, с высоким качеством зерна, устойчивы к прорастанию на корню и др. [2, 3].

В связи с этим поиск генотипов, доноров хозяйственно-ценных признаков, таких как короткостебельность, стабильная зерновая продуктивность, высокая конкурентоспособность по отношению к сорной растительности, устойчивость к фузариозу колоса и другим вредоносным организмам, является актуальным [1, 4].

Климатические условия 2016-2017 гг. характеризовались избыточным увлажнением с периода трубкования до молочной спелости. Они способствовали развитию заболеваний, в том числе фузариоза колоса и септориоза. Фенологические наблюдения проводили согласно методике государственного сортоиспытания сельскохозяйственных культур [6].

Учет продуктивности проводили взвешиванием после ручной уборки. Структуру элементов продуктивности изучали методом анализа выборки, состоящей из 15-20 растений.

Коллекция ВИР озимой тритикале представлена образцами из России - 36, в том числе из: Ростовской области - 5, Воронежской области - 1, Ленинградской области - 6, Дагестана - 17, Краснодарского края - 7, а также из Азербайджана - 1, Казахстана - 1, Польши - 4, Франции - 3, Чехии - 1, Швейцарии - 4, Болгарии - 4, Германии - 1, Швеции 1, Венгрии - 1, США - 2, Украины - 1.

Озимая тритикале в отличии от озимой пшеницы в меньшей степени поражается септориозом [5].

В фазе колошения - молочно-восковой спелости наиболее четко проявляются признаки этого заболевания на флаговом (последнем) листе. Результаты учета развития септориоза показали, что большинство сортообразцов имели зеленый, чистый от болезней флаговый лист в период молочной спелости.

Практически усохший фрлаг-лист от септориоза в фазе молочно-восковой спелости имели сортообразцы: Пушкинский 19/1, Раритет, Lamerto, Макар, Валентин 90, Князь, НТ 77, Дозор.

В таблице 1 представлены данные по анализу продуктивности сортов и образцов озимой тритикале коллекционного питомника.

Наибольшее значение длины колоса отмечено у образцов: Раритет, Гарнэ, ПРАГ 559, Адась, Топаз. В среднем значение длины у образцов озимой тритикале составило 10,5 cм. Масса зерна колоса является комплексным признаком, который характеризует массу одного зерна и общее количество зерен в колосе. По весу зерна с одного колоса из образцов озимой тритикале выделяются Топаз 2,8 г, Яша, Адась, Алмаз - по 2,7 г. Наименьший вес зерна с одного колоса у образцов АТПЛ - 1,5 г, Вокализ и Макар - 1,7 г.

По массе 1000 зерен лучший результат у образцов Легион - 49,3 г, Ратнэ - 49,0 г, Адась - 48,8 г.

Важным компонентом урожая считается число зерен в колосе [7].

Число зерен в колосе тесно связано с урожайностью и определяется условиями среды в периоды закладки, дифференциации колоса и цветения и может изменяться в широких пределах от 8-12 до 50-55 шт.

Устойчивость изучаемых сортообразцов и образцов к фузариозу колоса различна. Чем менее устойчив сорт к заболеванию, тем больше потерь в его продуктивности будет наблюдаться. Высокая биологическая урожайность (свыше 9 т/га) была получена у сортообразцов Pawo, Варвара, GR-162, Валентин 90, Trauwere, Osorno. Наибольшая зер-

Манукян Ирина Рафриковна - к. с.-х. н., Северо-Кавказский научно-исследовательский институт горного и предгорного сельского хозяйства Владикавказского научного центра Российской академии наук (СКНИИГПСХ ВНЦ РАН) (miririna.61@mail.ru).

"Басиева Мадина Ахсарбековна - к. с.-х. н. , СКНИИГПСХ ВНЦ РАН (basievane@rambler.ru). 
Структура продуктивности образцов и сортов озимой тритикале

\begin{tabular}{|l|c|c|c|c|c|}
\hline Сорт образец & $\begin{array}{c}\text { Фузариозных } \\
\text { зерен, \% }\end{array}$ & $\begin{array}{c}\text { Длина, } \\
\text { колоса, см }\end{array}$ & $\begin{array}{c}\text { Число зерен } \\
\text { волосе, шт. }\end{array}$ & $\begin{array}{c}\text { Масса зерна } \\
\text { с колоса, г }\end{array}$ & $\begin{array}{c}\text { Масса 1000 } \\
\text { зерен, г }\end{array}$ \\
\hline Яша & 8,5 & 8,0 & 31,8 & 2,7 & 34,8 \\
\hline Оsоrnо & 1,9 & 9,6 & 48,6 & 2,1 & 41,4 \\
\hline Вокализ & 4,3 & 10,3 & 39,0 & 1,7 & 43,0 \\
\hline Lamerto & 8,9 & 7,6 & 38,8 & 1,8 & 41,4 \\
\hline Веllac & 9,2 & 7,6 & 53,5 & 1,8 & 37,3 \\
\hline Адась & 1,1 & 11,8 & 54,7 & 2,7 & 48,8 \\
\hline Алмаз & 2,1 & 7,6 & 56,2 & 2,7 & 48,0 \\
\hline Легион & 9,5 & 8,2 & 41,8 & 2,1 & 49,3 \\
\hline Топаз & 1,2 & 11,7 & 44,5 & 2,8 & 35,9 \\
\hline Ring & 7,5 & 10,2 & 46,1 & 2,2 & 47,5 \\
\hline Тгашшег & 4,6 & 7,8 & 54,1 & 2,4 & 44,4 \\
\hline ПРАГ 7 & 1,4 & 8,0 & 39,2 & 1,7 & 45,0 \\
\hline Гарнэ & 7,9 & 12,0 & 55,8 & 2,4 & 42,8 \\
\hline Ратнэ & 10,8 & 10,1 & 42,5 & 2,1 & 49,0 \\
\hline Раритет & 1,8 & 12,8 & 55,1 & 2,6 & 47,9 \\
\hline Макар & 3,4 & 11,2 & 42,5 & 1,7 & 40,7 \\
\hline Валентин 90 & 8,7 & 10,0 & 42,2 & 2,3 & 40,6 \\
\hline ПРАГ 559 & 2,5 & 11,9 & 46,3 & 1,9 & 40,1 \\
\hline Сотник & 7,8 & 11,9 & 40,4 & 1,8 & 44,5 \\
\hline Рашо & 2,2 & 10,5 & 49,7 & 2,3 & 45,9 \\
\hline Тулус & 4,2 & 11,2 & 50,0 & 2,3 & 47,6 \\
\hline АТПЛ & 1,9 & 7,9 & 37,3 & 1,5 & 44,7 \\
\hline Варвара & 1,0 & 12,4 & 49,3 & 2,3 & 46,6 \\
\hline СR-16-2(Гор) & 2,1 & 13,1 & 51,0 & 2,3 & 45,1 \\
\hline
\end{tabular}

новая продуктивность выявлена у сортообразцов Топаз - 10,8 т/га, Адась - 10,6 т/га, Яша - 10,8 т/га, Алмаз - 11,5 т/га. Наименее продуктивные колосья отмечены у АТПЛ, ПРАГ-7, Lamerto, Bellac Вокализ и Макар - менее 7 т/га. По показателю количества фузариозных зерен в зерне менее 5 \% выделились сортообразцы: Варвара $(1,0 \%)$, Адась $(1,1 \%)$, Топаз (1,2 \%), ПРАГ-7 (1,4\%), Раритет (1,8 \%), Алмаз (2,1\%), ПРАГ-559 (2,5\%). Высокую степень поражения зерна фрузариозом имели следующие сортообразцы: Ратнэ (10,8 \%), Легион $(9,5 \%)$, Bellac $(9,2$ $\%)$, Lamerto (8,9\%), Валентин 90 (8,7\%), Яша (8,5 $\%)$, Сотник $(7,8 \%)$.

При изучении коллекции озимой тритикале ВИР выделены наиболее ценные сортообразцы, обладающие высокими показателями элементов продуктивности (число зерен в колосе, вес зерна с колоса, масса 1000 зерен ).

Больше 40,0 зерен в колосе образовалось у сортообразцов: Горка, Князь, Богдо, Кунак, ПРАГ 531, ПРАГ 512/1, ПРАГ 534, Vitalis, Triskell, SG-U-242, Grenado, Hortenso, Moderato, Prader, Tridel, Зенит одесский, КТ 15, TS 23, TS 80, AD Binova, HT/ 77,
Бард, Варвара, ПРАГ 506, Докучаевский 5, Завет, Дозор. Среди них выделяются образцы с числом зерен больше 50 шт. в среднем на колос: Князь - 55,5, ПРАГ 506 - 52,1, Докучаевский 5 - 54,3, Moderato - 64,7, Hortenso - 70,7 (табл. 2).

Устойчивость против полегания, которая в первую очередь зависит от высоты растения, является важнейшим свойством сортов интенсивного типа.

У озимой тритикале короткостебельных образцов значительно меньше, к ним относятся: Prego, Богдо, Кунак, Князь, KS 88 Т 142, Пушкинский 81/4, Пушкинский 95/4, Пушкинский 96/3, ПРАГ 531, ПРАГ 534, Самурай, Пушкинский 19/1, Сват, Рамзай, TS 44, Пушкинский 41/2, Triskell, Таза, Tridel, Дозор 67, TS 80, TS 23, Grenado, TS 45, Рамзай, Самурай.

По результатам первого года исследований выделены скороспелые образцы озимой тритикале: Рамзай, Горка, Князь, Богдо, Кунак, Сват, Зенит одесский, Vitalis TS 41, Пушкинский 41/2, Таза, Завет, HT/ 77, Дозор, Tridel, TS 80, TS 23, Grenado, TS 45.

Из образцов озимой тритикале по показателю массы 1000 зерен выделились: Рамзай, Князь, Бог- 


\section{Источники селекционно-ценных признаков озимой тритикале}

Таблица 2 мировой коллекции ВИР им. Н.И. Вавилова

\begin{tabular}{|c|c|}
\hline Признаки & Источникки \\
\hline $\begin{array}{c}\text { Число зёрен в колосе } \\
\text { (> 40,0 шт.) }\end{array}$ & $\begin{array}{l}\text { Горка, Князь, Богдо, Кунак, ПРАГ 531, ПРАГ 512/1, ПРАГ } \\
\text { 534, Vitalis, Triskell, SG-U-242, Grenado, Hortenso, Moderato, } \\
\text { Prader, Tridel, Зенит одесский, KT 15, TS 23, TS 80, AD } \\
\text { Вinova, НT/ 77, Бард, Варвара, ПРАГ 506, Докучаевский 5, } \\
\text { Завет, Дозор. }\end{array}$ \\
\hline $\begin{array}{c}\text { Высота растений } \\
\text { (105-110см) }\end{array}$ & $\begin{array}{l}\text { Prego, Богдо, Кунак, Князь, KS } 88 \text { Т 142, Пушкинский } 81 / 4 \text {, } \\
\text { Пушкинский 95/4, Пушкинский 96/3, } \\
\text { ПРАГ 531, ПРАГ 534, Самурай, Пушкинский } 19 / 1 \text {, Сват, TS } 44 \text {, } \\
\text { Пушкинский 41/2, Triskell, Таза, Tridel, Дозор 67, TS } 80 \text {, TS } 23 \text {, } \\
\text { Grenado, TS 45, Рамзай. }\end{array}$ \\
\hline $\begin{array}{l}\text { Скороспелость } \\
\text { (260-265 дней) }\end{array}$ & $\begin{array}{l}\text { Рамзай, Горка, Князь, Богдо, Кунак, Сват, Зенит одесский, } \\
\text { Vitalis TS 41, Пушкинская 41/2, Таза, Завет, НT/ 77, Дозор, } \\
\text { Tridel, TS } 80 \text {, TS 23, Grenado, TS } 45 \text {. }\end{array}$ \\
\hline $\begin{array}{c}\text { Мacca } 1000 \text { зёрен } \\
(>35,0 \text { г) }\end{array}$ & $\begin{array}{l}\text { Рамзай, Князь, Богдо, Кунак, Сват, ПРАГ 531, ПРАГ 518, } \\
\text { ПРАГ 512/1, ПРАГ 534, Таза, Vitalis, Triskell, SG-U-242, } \\
\text { Grenado, Hortenso, Moderato, Дозоp, Завет, Устинья, Варвара, } \\
\text { Бард, НТ 77, TS 45,TS } 80 \\
\text { АМ 4105, Prego, Зенит одесский, Bedretto, Tridel. }\end{array}$ \\
\hline $\begin{array}{c}\text { Масса зерна с } 1 \text { колоса } \\
(>1,5 \text { г })\end{array}$ & $\begin{array}{l}\text { Кунак, Prego, Князь, Рамзай, Богдо, ПРАГ 531, ПРАГ 518, } \\
\text { ПРАГ 512/1, ПРАГ 534, Дозоp, Vitalis, Triskell, SG-U-242, } \\
\text { Grenado, Hortenso, Moderato, Завет, ПРАГ 506, Устинья, AD } \\
\text { Binova, Зенит одесский, ТS 80, Бард, Prego. }\end{array}$ \\
\hline $\begin{array}{c}\text { Устойчивость к } \\
\text { фузариозу колоса } \\
\text { (до } 5 \text { \% больных зерен) }\end{array}$ & $\begin{array}{l}\text { Кунак, Bedretto, Бард, Сват, Hortenso, AD Binova, ПРАГ 531, } \\
\text { ПРАГ 512, Moderato, Triskel, TS 44, Докучаевскй 5, Устинья. } \\
\text { TS } 23 .\end{array}$ \\
\hline
\end{tabular}

до, Кунак, Сват, ПРАГ 531, ПРАГ 518, ПРАГ 512/1, ПРАГ 534, Таза, Vitalis, Triskell, SG-U-242, Grenado, Hortenso, Moderato, Дозор, Завет, Устинья, Варвара, Бард, НT 77, TS 45,TS 80, AM 4105, Prego, Зенит одесский, Bedretto, Tridel.

По показателю массы зерна 1 колоса выделились следующие образцы озимой тритикале: Кунак, Prego, Князь, Рамзай, Богдо, ПРАГ 531, ПРАГ 518, ПРАГ 512/1, ПРАГ 534, Дозор, Vitalis, Triskell, SG-U242, Grenado, Hortenso, Moderato, Завет, ПРАГ 506, Устинья, AD Binova, Зенит одесский, TS 80, Бард.
Таким образом, в коллекционного материале озимой тритикале выявлены сортообразцы, обладающие комплексом или отдельными хозяйственно-ценными признаками: Князь (Россия), Кунак (Россия), Богдо (Россия), Рамзай (Россия), ПРАГ 531 (Россия), Hortenso (Польша), Moderato (Польша), Зенит одесский (Украина), Pawo (Польша), Варвара (Россия), GR-16-2 (Россия) и др.

Эти и другие сортообразцы будут использованы в дальнейшей селекционной работе для получения новых линий и гибридов.

\section{ЛИТЕРАТУРА}

1. М.А. Басиева. Воздействие фрерментных препаратов на показатели всхожести зернобобовых культур // Научная жизнь, 2015. № 5. С. 35-40.

2. Лихненко С.В., Манукян И.Р. Проблемы фотосанитарного состояния сельхозугодий в РСО-Алания // Научная жизнь, 2014. № 6. С. 99-102.

3. Методика государственного сортоиспытания сельскохозяйственных культур. - М: Колос, 1971. 219 с.
4. Манукян И.Р., Басиева М.А. Агробиологическая характеристика зарубежных сортообразцов озимой тритикале в условиях предгорной зоны Северного Кавказа // Вестник АПК Ставрополья. 2017. № 2 (26). С. 191-193.

5. Манукян И.Р., Басиева М.А. Селекция озимой пшеницы на устойчивость к фузариозу колоса для условий предгорной зоны Северного Кавказа // Вестник АПК Ставрополья, 2016. № 3(23). C. 194-196.

\section{BECTHИK


6. Манукян И.Р., Басиева М.А. Селекция пшеницы и тритикале на устойчивость зерна к прорастанию на корню // Сборник: Актуальные и новые направления в селекции и семеноводстве сельскохозяйственных культур Материалы Международной научно-практической конференции, посвященной юбилею профрессора Сарры Абрамовны Бекузаровой, 2017. C. 40- 42
7. Басиева М.А., Манукян И.Р. Агробиологическая характеристика сортов озимой тритикале в условиях предгорной зоны Северного Кавказа // Сборник: Актуальные и новые направления в селекции и семеноводстве сельскохозяйственных культур Материалы Международной научно-практической конференции, посвященной юбилею профессора Сарры Абрамовны Бекузаровой, 2017. C. 42-45.

\title{
BREEDING EVALUATION OF WINTER TRITICALE GENE POOL OF THE IPI (ALL-RUSSIAN RESEARCH INSTITUTE OF PLANT INDUSTRY) WORLD COLLECTION IN THE CONDITIONS OF PIEDMONT ZONE OF THE NORTH CAUCASUS
}

\author{
I.R. Manukyan ${ }^{1}$, M.A. Basieva²
}

${ }^{1} \mathrm{PhD}$, The North Caucasian Research Institute of Mountain and Piedmont Agriculture

Vladikavkaz Scientific Centre of the Russian Academy of Sciences (miririna.61@mail.ru).

${ }_{2}^{2}$ PhD, The North Caucasian Research Institute of Mountain and Piedmont Agriculture Vladikavkaz Scientific Centre of the Russian Academy of Science (basievane@rambler.ru).

Abstract. In this article winter triticale varieties of the IPI (All-Russian Research Institute of Plant Industry named after N.I. Vavilov) world collection on the complex of agronomic characters are described. The sources of grain, shortstemness, sustainability to FHB (Fusarium head blight) high productivity have been identified. A collection of the initial material for the selection of the winter triticale varieties, adapted to the conditions of the piedmont zone of the North Caucasus has been made.

Keywords: winter triticale, world collection of VIR, Fusarium head blight, resistance.

\section{REFERENCES}

1. Basieva M.A. Vozdeystvie fermentnykh preparatov na pokazateli vskhozhesti zernobobovykh kul'tur // Nauchnaya zhizn', 2015. № 5. S. 35-40.

2. Likhnenko S. V., Manukyan I.R. Problemy fitosanitarnogo sostoyaniya sel'khozugodiy v RSO-Alaniya // Nauchnaya zhizn', 2014. № 6. S. 99-102.

3. Metodika gosudarstvennogo sortoispytaniya sel'skokhozyaystvennykh kul'tur. - M: Kolos, 1971. $219 \mathrm{~s}$.

4. Manukyan I.R., Basieva M.A. Agrobiologicheskaya kharakteristika zarubezhnykh sortoobraztsov ozimoy tritikale v usloviyakh predgornoy zony Severnogo Kavkaza // Vestnik APK Stavropol'ya. 2017. № 2 (26). S. 191-193.

5. Manukyan I.R., Basieva M.A. Selektsiya ozimoy pshenitsy na ustoychivost' k fuzariozu kolosa dlya usloviy predgornoy zony Severnogo Kavkaza // Vestnik APK Stavropol'ya, 2016. № 3(23). S. 194-196.

6. Manukyan I.R., Basieva M.A. Selektsiya pshenitsy i tritikale na ustoychivost' zerna k prorastaniyu na kornyu // Sbornik: Aktual'nye i novye napravleniya v selektsii i semenovodstve sel'skokhozyaystvennykh kul'tur Materialy Mezhdunarodnoy nauchno-prakticheskoy konferentsii, posvyashchennoy yubileyu professora Sarry Abramovny Bekuzarovoy, 2017. S. 40- 42.

7. Basieva M.A., Manukyan I.R. Agrobiologicheskaya kharakteristika sortov ozimoy tritikale $v$ usloviyakh predgornoy zony Severnogo Kavkaza // Sbornik: Aktual'nye i novye napravleniya $v$ selektsii $i$ semenovodstve sel'skokhozyaystvennykh kul'tur Materialy Mezhdunarodnoy nauchno-prakticheskoy konferentsii, posvyashchennoy yubileyu professora Sarry Abramovny Bekuzarovoy, 2017. S. 42-45. 